\title{
VINKO JELIĆ AND IVAN LUKAČIĆ TWO MIGRANTS BETWEEN THE MEDITERRANEAN AND CENTRAL EUROPE IN THE MUSMIG PROJECT AND ITS DATABASE
}

\author{
VJERA KATALINIĆ \\ Hrvatska akademija znanosti i umjetnosti, Zagreb
}

\begin{abstract}
Izvleček: Avtorica opisuje faze nastajanja podatkovne zbirke evropskega projekta HERA Glasbene migracije v zgodnjem novem veku: na stičišču evropskega vzhoda, zahoda in juga (2013-2016) na primeru dveh glasbenikov z današnje Hrvaške. Vinko Jelić z Reke in Ivan Lukačić iz Šibenika sta bila sodobnika generacije skladateljev, znanih iz zbirke Parnassus musicus Ferdinandaeus. Njunih skladb ta antologija ne vključuje. Podatki o njunem življenju, izobrazbi in delu so bili priobčeni v podatkovni zbirki projekta MusMig skupaj s tistimi o drugih 3500 tovrstnih evropskih glasbenikih. Rezultati iskanja po zbirki omogočajo vpogled v njuni časovnici in možne stike $z$ drugimi glasbeniki.
\end{abstract}

Ključne besede: Vinko Jelić (1596 - po 1636), Ivan Lukačić (1587? - 1648), glasbeniki migranti, 17. stoletje, projekt HERA MusMig, podatkovna zbirka.

\begin{abstract}
The author presents phases in the work on the database within the European HERA project Music Migrations in the Early Modern Age: the Meeting of the European East, West and South (2013-2016), illustrated by two case studies from the Croatian lands. Vinko Jelić from Rijeka and Ivan Lukačić from Šibenik were contemporaries of the Parnassus Musicus Ferdinandaeus generation but their output was not included in the anthology. The data on their life, education and work was entered in the database, as well as data on 3500 other European musicians investigated in the MusMig project. On the basis of the search results, their timelines and possible encounters with other musicians are outlined.
\end{abstract}

Keywords: Vinko Jelić (1596-after 1636), Ivan Lukačić (1587?-1648), migrant musicians, seventeenth century, HERA MusMig project, database.

Elementary research on Vinko Jelić and Ivan Lukačić, two important musicians and composers from early seventeenth-century Croatia and contemporaries of the composers in Parnassus Musicus Ferdinandaeus, was begun some seventy to eighty years ago. After basic information on Jelić was published in the most notable historical lexicons (Walther, Gerber and Fétis), ${ }^{1}$ more recently his work was mentioned in the $\mathrm{PhD}$ thesis Die

1 In these secondary sources, data on Jelić were taken over from introductions to his own three published collections of concerti ecclesiastici: cf. Jelić, Parnassia militia; Jelić, Arion primus; Jelić, Arion secundus. 
Anfänge des geistlichen Konzerts by Adam Adrio in 1935; ${ }^{2}$ Hellmut Federhofer supplied an extensive bibliography and further data on Jelić in $1955,{ }^{3}$ followed by the publication of his music with introductory studies by Albe Vidaković in $1957,{ }^{4}$ and by Lovro Županović in $1970 \mathrm{~s}^{5}$ and $1980 \mathrm{~s}^{6}{ }^{6}$ The first contemporary performance of some compositions by Jelić was organised by Dragan Plamenac in Zagreb in 1935, when three ricercari for cornetto and trombone were performed as part of his concert series "Iz hrvatske muzičke prošlosti" (From the Croatian musical past). In this concert series, compositions by the other composer under consideration here, Ivan Lukačić, were also included. The earliest information on him dates back to $1924^{7}$ and $1925,{ }^{8}$ while Dragan Plamenac published updated results in Croatia and abroad of the research on his life and opus between $1935^{\circ}$ and $1969,{ }^{10}$ with some later supplements by Ivan Bošković in 1977 and others. ${ }^{11}$ These rudimentary data on both musicians have more or less served unaltered up to today, except for some later additions mostly concerning the context of their work. The biographical data on both of them are rather modest, and there are still some doubts relating to their timelines, musical encounters and compositional activities.

Within the existing literature, these uncertainties are partly explained and qualified by adequate hypotheses. However, when these data are about to be entered into a computer database, some problems occur and certain principles have to be established and followed in order to obtain the expected results. Examples of such dilemmas - applied to the life and activity of these two composers, elaborated within the European HERA project Music Migrations in the Early Modern Age: the Meeting of the European East, West and South (MusMig, 2013-2016) - are presented here within the context of the task of entering data on both composers - contemporaries and members of the Parnassus Musicus Ferdinandaeus generation - into the database.

The MusMig project team consisted of six working groups, with the one from Berlin (Martin Albrecht-Hohmeier from Berlin-Brandenburgische Akademie der Wissenschaften with collaborators) being in charge of the MusMig webpage ${ }^{12}$ and the online database. ${ }^{13}$

2 Adrio, Die Anfänge des geistlichen Konzerts.

3 Federhofer, "Vincenz Jelich", 215-227.

4 Albe Vidaković published data on Vinko Jelić in 1957, as an introductory study of his collection of spiritual concerti and ricercari entitled Parnassia militia (cf. Vidaković, "Uvod" [with summaries in German, French and English]).

5 Županović, "Vinko Jelić"; Jelić, Osemnaest moteta.

6 Županović, Centuries of Croatian music, 86-98; Županović, "Umjetnost ranobaroknog hrvatskog skladatelja Vinka Jelića Riječanina”, 35-37. See also: Bujić and Tuksar, “Jelić, Vincenz”, 940.

7 Kalogjera, "Povijesne crtice".

8 Mantuani, "Glasbeniki iz reda sv. Frančiška".

9 Plamenac published a selection of sixteen Lukačić's motets with an initial study at Hrvatski glazbeni zavod (Plamenac, "Predgovor").

${ }^{10}$ One of the most thorough texts is Plamenac, "Tragom Ivana Lukačića".

${ }^{11}$ For a thorough bibliography cf. Stipčević, Ivan Lukačić, 147-149. In this publication, Stipčević collected the majority of known data on Lukačić and his compositions and placed them in the cultural context of his time.

$12 \mathrm{http} / / /$ www.musmig.eu/.

${ }^{13} \mathrm{http} / / /$ www.musmig.eu/database-test3/. 
In the project plan, the establishment and the development of the database was conceived as follows:

1) The initial stage of information and research will consist of putting together already available and not yet interconnected data on migrating musicians in Eastern, Western and Southern Europe (...).

2) The second level of research is that of entering the material collected in this way into the central CRP database. This database already existed as a primary nucleus in the form of the previously developed computer database of the ANR-DFG project Musici (January 2010 - December 2012) on European musicians in Venice, Rome and Naples (1650-1750), which used a system for collecting and structuring of personal data ("Personendaten-Repositorum" - PDR), developed within a DFG-project of the Academy of Sciences in Berlin. The data in the database - more precisely in the "Archiv-Editor" computer program - include information on forms of names, dates of birth and death, relatives, teachers, schooling, general information on gender, profession and cultural origin (i.e., mother tongue), musical and other activities, memberships, journeys and sojourns (with dates and locations), patrons and salaries. In this way, the existing MUSICI-project was planned to be considerably enlarged with data on new music personalities and their activities, and other musical phenomena (social aspects, aesthetical aspects, compositional styles and performing practices), in order to become a shared tool making it possible to study the dynamics of the different directions of migration.

3) The third level of research has been the creation of a European map of migrating musicians (according to various parameters, concerning the special profiles of musicians according to nationality, musical education, professional activity etc.) which would produce a set of musical junctions as centres of the most intense musical life. In this way, the already established networks were enlarged with new locations, areas and regions of the common European musical-cultural space. (...)

All phases of the database work include the specifying of data fields and vocabulary, their modification according to new needs (specific types of information) and the adjustment of the "Archiv-Editor" in line with the possible changes occurring during the research process. The last phase includes the visualization of the database on migrant musicians and its online publication on the web page of the project.

The first two stages - i.e., collecting and entering data on musicians into the database via Archiv-Editor - lasted throughout the project and had been accomplished and made visible (and searchable) by its end (30 November 2016). During the project four research groups entered at total of 3502 historical names of musicians, ${ }^{14}$ comprising all known data such as biographical information and profession, name variants, schooling, employment, travels, works, bibliography etc.

The Lukačić case highlights some general principles when dealing with historical persons: his original given and monastic names (Marcus, Ioannes) as well as his family name (Lucacich, Luccacich, Lucacih) were Croaticised in the Croatian literature (Ivan

${ }^{14}$ The partner group from Croatia: 515 names; the partner group from Mainz: 1,470 names; the two groups from Warsaw: 609 names; and the partner group from Slovenia: 638 names. 
[Marko] Lukačić), and this version was established as the one appropriate for encyclopaedia entries. However, all variants have been entered into the MusMig database, where the standardised version ${ }^{15}$ is the main entry, in order to enable various search combinations. Another obstacle in this "Croatian case" discussed here proved to be the entry of his date of birth. This date has been discussed in almost all previously mentioned publications, but there are also sources of information on the internet that users frequently consult in the first instance. Thus it happens that they obtain incorrect or inadequate information, a point that has to be highlighted here: the Croatian Wikipedia ${ }^{16}$ gives very scanty information, stating, without any supporting arguments, that Lukačić was possibly born in 1575. Fortunately, other internet sources give more precise information derived from research - i.e., specifying the year 1585 or a year between 1585 and $1587^{17}$ as his date of birth - although the only known document of relevance is his baptismal certificate dated 1587. ${ }^{18}$ That date should accordingly be considered as the only reliable and undisputable piece of information, as Bojan Bujić gives it in the New Grove. ${ }^{19}$ Conversely, the New Grove article contains a different error: namely that Lukačić's sole musical collection, Sacrae cantiones, was published in Venice in 1629, and not in 1620 as stated correctly in the Croatian Wikipedia. ${ }^{20}$ Since the first-named encyclopaedia is expected to offer information of the highest reliability, this error had to be commented on in the database.

The present facts about Ivan Lukačić tell us that he was baptized in Šibenik (Sebenico, in 1587); in 1597 he entered the Franciscan monastery there and in 1600 was sent to Italy for further education. In 1612 he gained the baccalaureate (at the age of 25?), and on 1 September of the same year he was elected custode of the Zadar Custody. After refusing to accept this post, he returned to Italy in 1613. The documentation attests that on 30 September 1614 he acted as the maestro di cappella per la festa di S. Girolamo in Rome, while soon afterwards Lukačić obtained the title of magister musices (23 March 1615). No information on his teachers, fellow students or meetings with contemporary musicians is given in the preserved documentation. The only possible hint of a "professional" encounter might concern the composer Gabriello Puliti, who was active in Istria and belonged to the same Franciscan province. However, the MusMig database, thanks to various entries, suggests some possible encounters by Lukačić during his sojourn in Rome (1613-1616): Bartol Kašić (Bartholomaeus Cassich) from Dubrovnik travelled in 1613 to Rome; between 1611 and 1621 Giovanni Francesco Anerio was active in Rome as maestro di cappella at the Church of Santa Maria dei Monti. Anerio also occasionally served as organist at the "Croatian church" of San Girolamo dei Schiavoni. The singer Pellegrino Muti served in 1614 as a court musician of Cardinal Alessandro Peretti di Montalto; and the cornettist Georg Simonidis was a member of the "Suonatori del Conversatori" in Rome until 1614.

${ }^{15}$ The standardised version was taken over following RISM principles: i.e., in conformity with the main general and national music encyclopaedias (New Grove, $M G G$, etc.).

${ }^{16}$ Cf. Croatian Wikipedia, s.v. "Lukačić, Ivan".

${ }^{17}$ Cf. Nova Akropola, s.v. "Lukačić, Ivan".

${ }^{18}$ As stated in the English Wikipedia, s.v. "Lukačić, Ivan", and in the Hrvatska enciklopedija, s.v. "Lukačić, Ivan".

${ }^{19}$ Bujić, "Lukačić", 288.

${ }^{20}$ Unfortunately, the error of dating has not been corrected in the Grove Online version of 2013. 
Possible new findings on Lukačić's education during the first decade of the seventeenth century could give rise to further speculation about his encounters.

In September 1616 Lukačić refused to accept once more his nomination as guardian of the Franciscan monastery in his native Šibenik and stayed in Italy for two more years before returning to Šibenik in 1618. Did Lukačić spend time in Venice, the musically important centre where in 1620 he published his collection Sacrae cantiones? ${ }^{21}$ Venetian publishers were popular with musicians coming not only from the eastern Adriatic coastline, such as Gabriele Sponga Usper, originating from Poreč (Parenzo) in Istria, who published his collections Messa, e salmi (1614) and Compositioni armoniche (1619) there and later acted as organist at the ducal church of S. Marco. At that time Pietro Paolo Meli from Reggio Emilia published his volumes entitled Intavolatura di liuto attiorbato (in 1614, 1616 and 1620), and in 1618 the first volume of Sacrorum concentuum by Giovanni Prioli (Priuli) was published there. Last but not least, in 1615 the Parnassus collection was printed there as well. However, in 1620 Lukačić moved from Šibenik to Split, where he remained for good, dying in 1648 .

The second composer under consideration here is Vinko Jelić (1596-after 1636), in documents known mostly as Vincenz(o) Jelich (sometimes Jelicich), who in 1606 left his native Rijeka (Fiume, Flumen Sancti Viti, St Veit am Pflaum) at the early age of eleven, together with his elder brother Petrus (who died in 1609). Their father sent them to Graz, where they were schooled and served in the court chapel of the Archduke Ferdinand. Their teacher was the Italian musician Matthia Ferrabosco. After a short sojourn in Rijeka (at the time when his voice broke, and after Petrus' death), Vincenz returned to Graz in 1610, entered the Ferdinandaeum and continued his education, acting initially as a treble in church music performances and then from 1615 onwards as an instrumentalist in the court chapel. In 1617 Jelić terminated his studies in theology, moving a year later to Alsace in the service of the court of Ferdinand's brother Leopold, Bishop of Strasbourg and Passau, who resided at Saverne (Ger. Zabern). There Jelić was ordained as a priest; in 1618 he became a vicar, and in 1622 a canon. At the same time he served as a musician in Leopold's court chapel: as a tenor and, later, an instrumentalist. His known and preserved œuvre consists of three collections of concerti spirituali published in Strasbourg in 1622 (Parnassia militia) ${ }^{22}$ and 1628 (Arion primus, ${ }^{23}$ Arion secundus). ${ }^{24}$ The last document mentioning Jelić dates from 1636, when he is still named as a canon at the collegiate church of St Mary in Saverne. The battles and pestilences of the Thirty Years' War could well have lain behind his disappearance.

Thanks to the well-preserved documentation in Graz, a series of documents have survived. There are some letters by him and his father, as well as documentation regarding his professional life and movements. His teacher is known: Matthias Ferabosco. Federhofer assumes that the singer and composer Raimundo Ballestra invited him to Saverne, and Jelić was undoubtedly known to Johannes Donfried, who in 1627 published

\footnotetext{
21 Lukačić, Sacrae Cantiones.

22 Jelich, Parnassia militia.

23 Jelich, Arion primus.

24 Jelich, Arion secundus.
} 
two collections of church music in Strasbourg, where he included six of Jelić's works (as well as ones by Lukačić!), ${ }^{25}$ along with motets by Anerio, Grandi, Hassler etc. Further on, we find a list of musicians active in Graz during Jelić's period at Ferdinand's court, these being men who also contributed to the Parnassus collection. Among musicians who might have been in contact with Jelić were Georg Poss, who stayed on as an instrumentalist in Ferdinand's court chapel until 1618; the already mentioned Giovanni Priuli (Prioli), who in 1614 or 1615 became maestro di cappella there before moving to Brixen; Giovanni Sansoni, from 1613 a cornett player in Graz, who later followed the Archduke to Vienna; Alessandro Tadei, since 1606 court organist in Graz, and Giovanni Valentini, who arrived at the Graz court in 1614 as the "newly appointed chamber organist from Poland". As emerges from the MusMig database, during Jelić's period in Graz many more singers or instrumentalists were active there, mostly in the court chapel of Archduke Ferdinand II, such as the altos Francesco Casani, Giulio Cesare Russini (Rosini) and Canciano Cividino, the instrumentalist Francesco Degli Atti, the instrumentalists and trumpeters Balthasar Pirnsteiner (Pernstein), Hans Fabricius (Fabrici), Heinrich Kholb and Ruprecht Pokhstaller, the Kapellknaben Jeremias de Leo, Wolfgang Cäpell (Capel), Nicolo Cavalletti Fiorentino and Alessandro Rossi, the bass player Elias Thaber and Johann Fabrus, the trumpeter and timpanist Andreas Speyrer, the trumpeter Reinhardt Stum and many others. Some of them returned to their native regions, some continued with their education (at the local Jesuit College or elsewhere), and some developed their musical career in Graz, Vienna, Prague or somewhere else.

Besides the already-mentioned Raimundo Ballestra, Georg Poss, Giovanni Priuli (Prioli), Giovanni Sansoni, Alessandro Tadei and Giovanni Valentini belonging to the list of 32 composers whose works were included in the Parnassus collection, only three further names occur in the database of our project: Giovanni Battista Cocciola, Giulio Osculati and Michelangelo Rizzio.

Coinciding (partly) with Vincenz Jelić's period of service in Graz, two ecclesiastics from Croatian lands were also there: Nicolaus Sartorius (Krajačević), ${ }^{26}$ a Jesuit from Northern Croatia, who studied philosophy (1606-1609) and theology (1616-1617), later publishing texts of church songs translated from Latin into the Kajkavian dialect of the Croatian language (the first edition is lost; the second edition was published in Bratislava in 1740). The second one was Athanasius Georigiceus (Jurjević), ${ }^{27}$ another Jesuit, writer and diplomat, originating from Split, who in 1611 completed his studies in philosophy at the Jesuit College there. In 1635 Georgiceus published in Vienna a collection of simple church songs Pisni za naypoglavitiye, naysvetiye i nayveselye dni (Songs for major, most holy and most joyous days) for voice and organ basso continuo.

As we have seen, the data on Jelić reveal, thanks to the rather ample information collected within the MusMig project, quite a lot of possible encounters with the active musicians who introduced the new Italian style into the church music of Central Europe. At the time when the Parnassus collection was assembled and published, he was obviously

${ }^{25}$ Cf. digitalized version: http://dizbi.hazu.hr/object/3501.

${ }^{26}$ Cf. Jembrih, "Krajačević".

${ }^{27}$ Breko, "Jurjević". 
too young and inexperienced as a composer to contribute to it. Only seven years later was he to make public his compositional skills, becoming successful enough to have his music included in similar collections - the Donfried publications.

In the MusMig project such timelines and encounters, or junctions, as presented in the two case studies here, have been visualised in the form of chronologies/timelines and maps (see the two illustrations). The quality of the database is critically reliant on the quantity of input data. It will be available only during the next few months, according to the requirements of the HERA consortium agreement, and the members of the MusMig group are currently seeking the possibility of keeping this valuable part of the project work available for future use. Whatever happens, the aim of the database has been to serve as a basis for investigation and enable deeper insights into such junctions and/or meeting points, which can have brought both cooperation or rivalry to the lives of musicians, and which also create a point of departure for the investigation of their mutual influence.

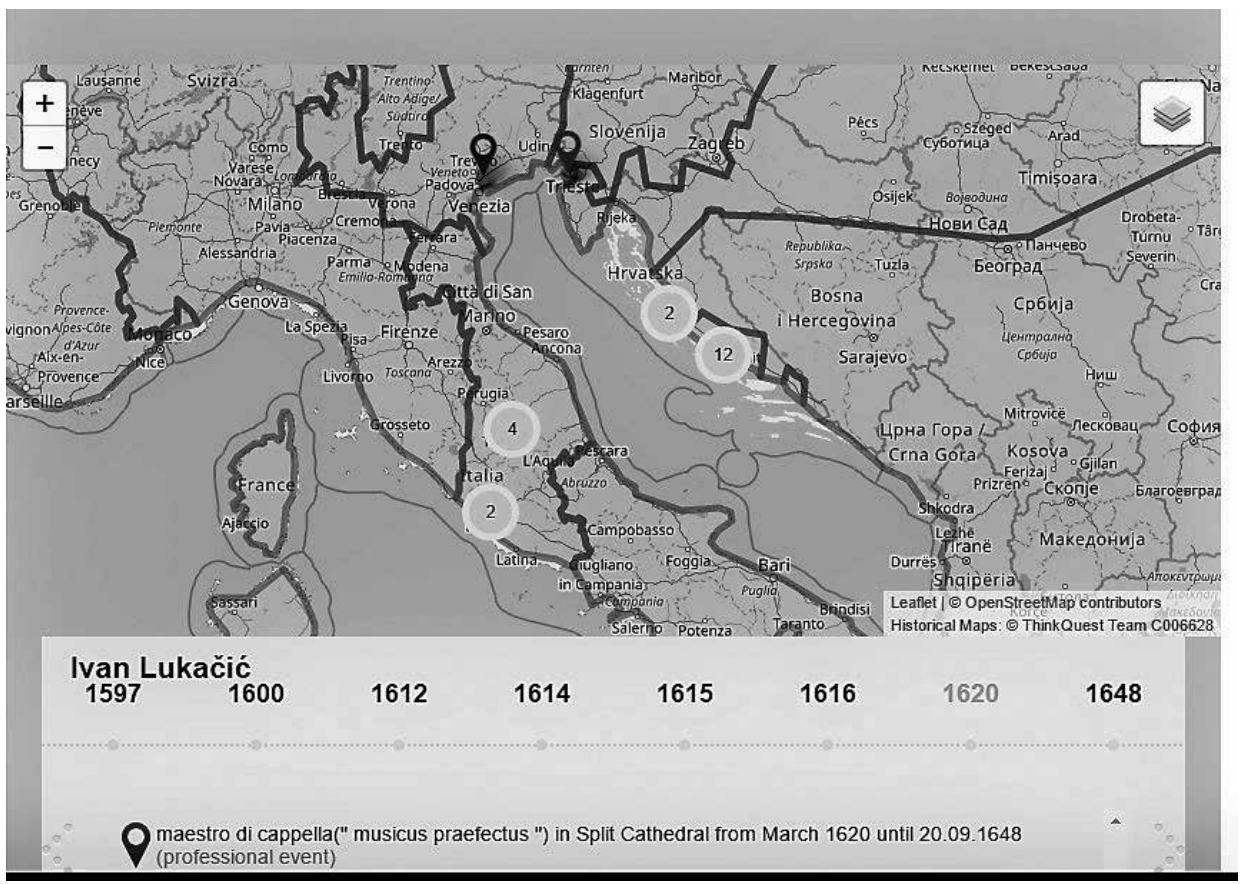

Figure 1

Activities of Ivan Lukačić in 1620, as presented on the timeline and interactive map of the MusMig database 


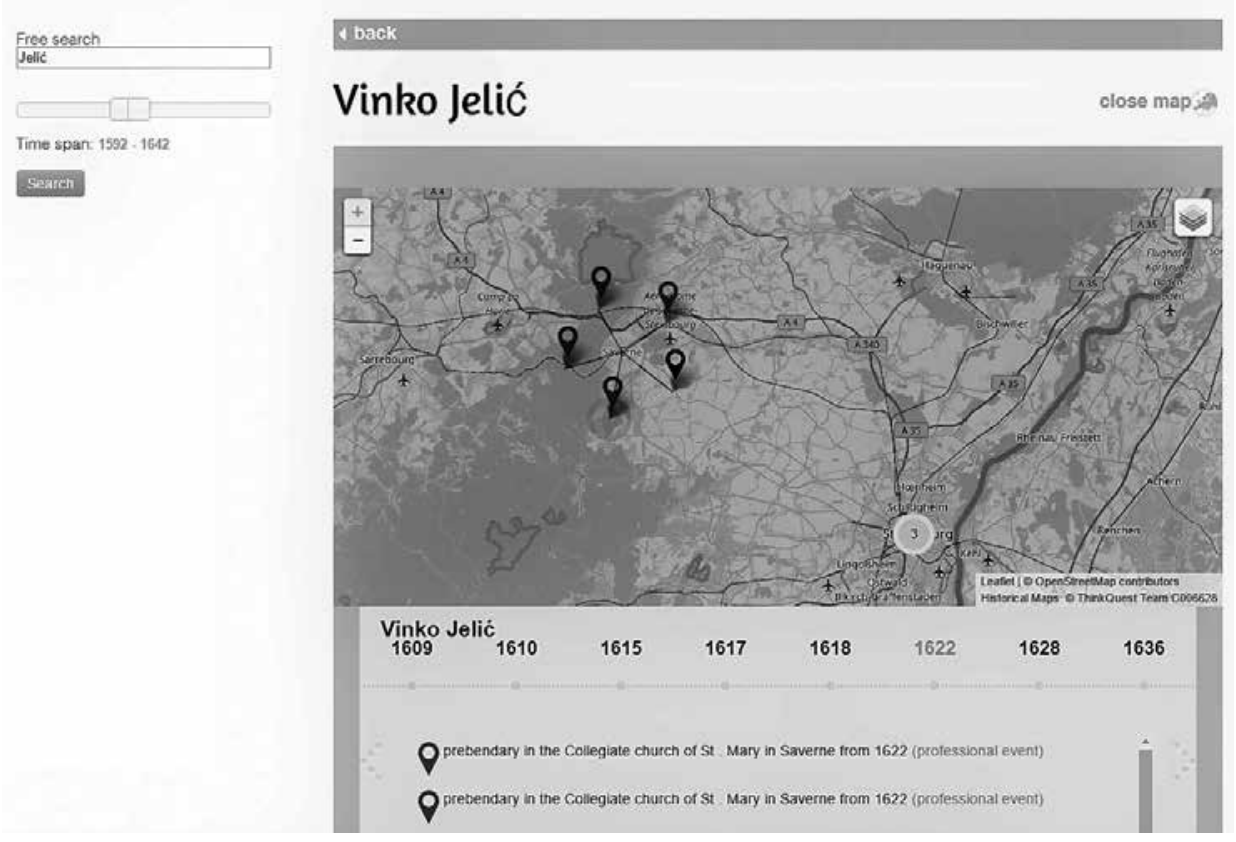

\section{Figure 2}

Activities of Vinko Jelić in 1622, during his sojourn in Saverne near Strasbourg, as presented on the timeline and interactive map of the MusMig database

\section{Bibliography}

\section{EARLY Music Prints}

Jelich, Vincenz. Arion primus sacrorum concertuum. Unius, duarum, trium et quatuor vocum ad organum concinendarum. Opus secundum. Strasbourg: Paul Ledertz, 1628. RISM J 521.

___ Arion secundus psalmorum vespertinorum tam de tempore, quam de Beata Maria Virgine quatuor vocibus, alternatim ad organum concinendarum adiunctis Magnificat, Salve regina, \& octo tonis ad omnia strumenta accomodatis. Opus tertium. Strasbourg: Paul Ledertz, 1628. RISM J 522.

- Parnassia militia concertuum unius, duarum, trium et quatuor vocum tam nativis quam instrumentalibus vocibus, ad organum concinendarum. Opus primum. Strasbourg: Paul Ledertz, 1627. RISM J 520. http://dizbi.hazu.hr/object/3520.

Lukačić, Ivan. Sacrae cantiones singulis, binis, ternis, quaternis, quinisique vocibus concinendae. Venice: sub signo Gardani, 1620. RISM L 2928a. 


\section{LITERATURE}

Adrio, Adam. Die Anfänge des geistlichen Konzerts. Berlin: Junker und Dünhaupt, 1935. Ajanović-Malinar, Ivona. "Jelić, Vinko". In Hrvatski biografski leksikon. Accessed 2 January 2017. http://hbl.lzmk.hr/clanak.aspx?id=141.

Breko, Hana. "Jurjević, Atanazije (Georgiceo, Georgiceus, Jurievich-Dalmata; Athanas, Athanasius)". Hrvatski biografski leksikon. Accessed 5 January 2017. http://hbl.lzmk. hr/clanak.aspx?id=9296.

Bujić, Bojan. "Lukačić, Ivan". In The New Grove Dictionary of Music and Musicians, 2nd ed., edited by Stanley Sadie, 15:288. London: Macmillan, 2001.

___ a and Stanislav Tuksar. "Jelić, Vincenz". In The New Grove Dictionary of Music and Musicians, 2nd ed., edited by Stanley Sadie, 12:940. London: Macmillan, 2001. Federhofer, Hellmut. "Vincenz Jelich". Archiv für Musikwissenschaft 12, no. 3 (1955): 215-227. https://doi.org/10.2307/929603.

Jelić, Vinko. Osamnaest moteta iz zbirke “Arion primus” (1628). Edited by Lovro Županović.

Zagreb: Društvo muzičkih radnika Hrvatske - Croatia Concert, 1977.

Jembrih, Alojz. “Krajačević, Nikola (Sartorius)”. In Hrvatski biografski leksikon. Accessed 5 January 2017. http://hbl.lzmk.hr/clanak.aspx?id=10670.

Kalogjera, Niko. "Povijesne crtice o glazbenim prilikama splitske stolne crkve". Sv. Cecilija 17, no. 3 (1924): 89-90; no. 4: 126-128; no. 5: 160-163. Accessed 2 January 2017. http:// dnc.nsk.hr/journals/LibraryTitle.aspx?id=227b974b-8745-45da-a033-6e08fc3367a0\#.

Wikipedia. Accessed 1 October 2016. http://hr.wikipedia.org.

Wikipedia. Accessed 1 October 2016. https://en.wikipedia.org.

Hrvatska enciklopedija. Accessed 1 October 2016. http://www.enciklopedija.hr.

Nova Akropola. Accessed 1 October 2016. http://nova-akropola.com/lijepe-umjetnosti/ glazba/ivan-lukacic/.

Mantuani, Josip. “Glasbeniki iz reda sv. Frančiška”. Nova revija 4, no. 1 (1925): 41-59; no. 2: 146-163; no. 3: 266-277; no. 4: 368-378.

Plamenac, Dragan, "Predgovor". In Ivan Lukačić, Odabrani moteti (1620), edited by Dragan Plamenac, 3-10. Zagreb: Hrvatski glazbeni zavod, 1935.

___ "Tragom Ivana Lukačića i nekih njegovih suvremenika". Rad 2 (1969): 63-90.

Stipčević, Ennio. Ivan Lukačić. Zagreb: MIC, 2007.

Vidaković, Albe. "Uvod”. In Vinko Jelić (1596-1636?) i njegova zbirka duhovnih koncerata i ricercara Parnassia militia (1622), VII-XCIII. Zagreb: JAZU, 1957.

Županović, Lovro. "Vinko Jelić u svjetlu svoje zbirke 'Arion primus' (1628)”. In Osamnaest moteta iz zbirke "Arion primus" (1628) by Vinko Jelić, edited by Lovro Županović, IX-XIX. Zagreb: Društvo hrvatskih skladatelja, 1974.

. Centuries of Croatian music. Vol. 1. Zagreb: MIC, 1984.

- "Umjetnost ranobaroknog hrvatskog skladatelja Vinka Jelića Riječanina u svom vremenu i danas". Glasnik 39 (1986): 35-37.

- “Arion secundus' Vinka Jelića”. In Arion secundus (1628) by Vinko Jelić, VIIXIII. Zagreb: Društvo muzičkih radnika Hrvatske - Croatia Concert, 1977. 


\section{VINKO JELIĆ IN IVAN LUKAČIĆ \\ MIGRANTSKA GLASBENIKA MED MEDITERANOM IN SREDNJO EVROPO V PROJEKTU MUSMIG IN NJEGOVI PODATKOVNI ZBIRKI}

Povzetek

O dveh zgodnjebaročnih skladateljih na ozemlju današnje Hrvaške - Vinku Jeliću (Reka, 1596 - Saverne (?) po 1636) in Ivanu Lukačiću (Šibenik, krščen 1587 - Split, 1648) ne vemo veliko. Pogosto manjkajo celo najosnovnejši podatki, o dnevu rojstva ali smrti, o učiteljih in sodelavcih, o poteh. Lukačić se je šolal v Italiji, kjer je nekaj časa tudi deloval, medtem ko je Jelić svoje šolanje začel v Ferdinandeumu v Gradcu, a je pozneje deloval v alzaškem kraju Saverne, kjer se po letu 1636 za njim izgubi vsaka sled. Oba sta bila duhovnika, skladatelja in sodobnika generacije, ki je svoje skladbe prispevala za antologijo Parnassus musicus Ferdinandaeus (1615). Njunih skladb v tej sicer ni. Jelić je bil premlad in Lukačić ni pripadal eminentnemu srednjeevropskemu krogu skladateljev omenjene zbirke.

V okviru raziskav evropskega projekta HERA Glasbene migracije v zgodnjem novem veku: na stičišču evropskega vzhoda, zahoda in juga (2013-2016) je bila deležna pozornosti tudi njuna mobilnost. Znani podatki o tej skladateljski dvojici in njunih objavljenih zbirkah so bili skupaj s podatki o drugih 3500 glasbenikih vključeni v interaktivno spletno zbirko podatkov. Iz tako pridobljenih časovnic njunih poti, mest srečevanj in križanj je $\mathrm{V}$ zvezi z njima prišlo na dan še nekaj drugih imen glasbenikov, s katerimi bi lahko Lukačić in Jelić med svojimi potovanji prišla $\mathrm{v}$ stik in si z njimi izmenjala glasbene, še posebno skladateljske izkušnje. 